\title{
Comparison of the Bioeffect of Different Locally Isolated Antifungal Bacteria
}

\author{
Omar Mu'ayad Al-Obaidy \\ Department of Biology / College of Science \\ University of Mosul
}

Received

06 / 04 / 2010
Accepted

05 / 05 / 2010

\section{الخلاصة}

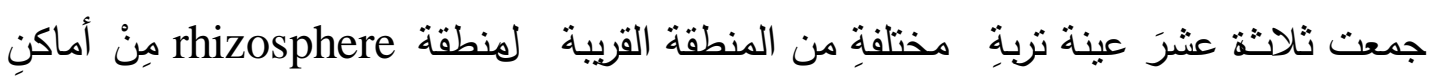

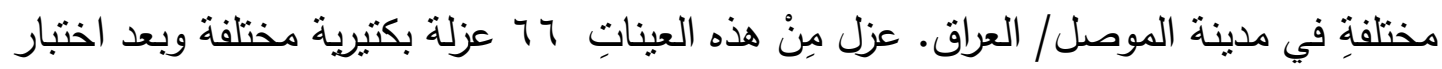

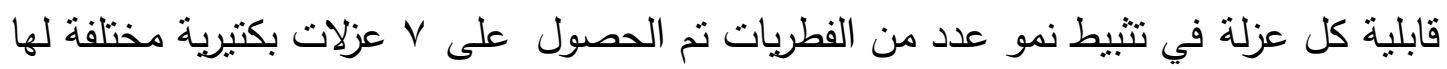

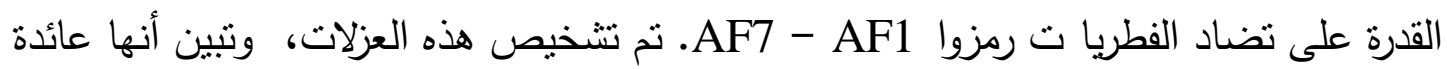

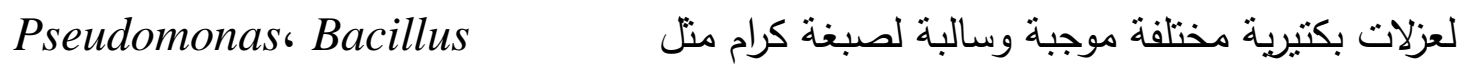

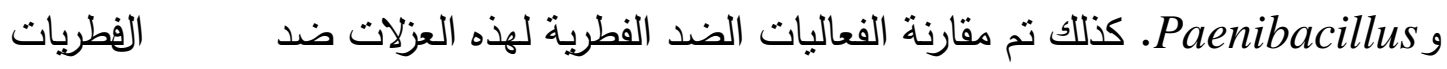
(أظهرت النتائج بان هناك

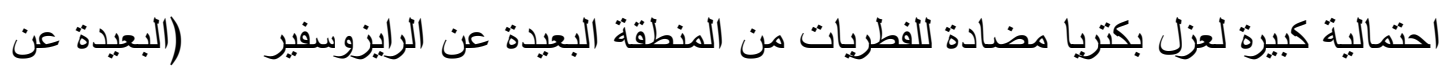
جذور النباتات ) (ومن المكن استخدام هذه العزلات للمقاومة

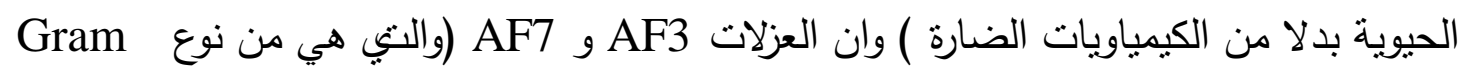
(positive

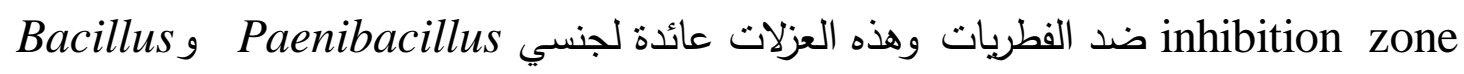
على التوالي وان سبب التثبيط هو إنتاج مواد مثبطة للفطريات أو مضادات التهات حيوية .antibiotics

\begin{abstract}
Thirteen different soil samples near the rhizosphere were collected from different places in Mosul city/ Iraq. Sixty six different bacterial isolates were isolated from these samples. After testing the capability of each one of these isolates in antagonizing some pathogenic fungi we had 7 different bacterial isolates with an antifungal activities. They were designated as AF1-AF7. An identification of these bacteria was done, and
\end{abstract}


they appeared to belong to different Gram positive and Gram negative bacteria such as Bacillus, Pseudomonas, and Paenibacillus. The antifungal activities of these bacteria were compared between each other on the pathogenic fungi Fusarium, Penicillium, Alternaria, and Aspergillus. The results showed that there is a high probability of isolating different potent antifungal bacteria from the non root-associated soils (and they could be used as potent biological control agent instead of harmful chemicals). The isolates AF3 and AF7 were the most active isolates against the test fungi because of their high inhibition zones and they were belonged to Gram Positive bacteria Paenibacillus and Bacillus respectively, and the inhibition was due to the production of antifungal metabolites or antibiotics.

\section{Introduction}

Most of the important cereal crops in the world are prone to many soil-borne plant pathogens that reduce the quality and quantity of grain production (1). Fungi are the primary causes of grain loss, and some of them produce compounds that are toxic when consumed (2). Fungal diseases of plants are usually controlled by some combination of cultural practices, including the use of fungicides, and increasing the plant host resistance. Fungicides are the primary means of fungal disease control, but their use is currently controversial because investigation have indicated potentially undesirable environmental side effects (3).

Due to environmental concerns, there is a considerable interest in finding alternatives to chemical pesticides for suppression of soil borne plant pathogens. Biological control represents an attractive alternative for the future because of the many concerns about the pesticides use. Ideally, an agent of biological control of fungal root pathogens should exert a sufficient amount of antagonistic activity in the rhizosphere to significantly reduction in root disease symptoms (4).It was mentioned by many researches that the soil, especially the rhizosphre, contains different kinds of bacteria (Gram positive and Gram negative) that positively affect the plant, especially by antagonizing the soil borne plant pathogenic fungi $(5,6,7$,and 8). According to this we aimed in this study to isolate (and to know) different types of bacteria from the non-rhizosphere soils that have antifungal activities toward different plant and human pathogenic fungi (they might be used as good biological control agent) and to compare the antifungal activity between each one of these bacteria.

\section{Materials and Methods}

Test fungi:

The Plant pathogens Penicillum nalgiovense, Fusarium graminearum, Alternaria alternata, and one human fungal pathogen Aspergillus niger were obtained from Biology Department/ College of Science/University of Mosul/Iraq. 


\section{Collection of samples:}

Thirteen different soil samples (garden soils) were collected from different places in Mosul city, garden soil samples of Al-Faesalia region (3 samples), Al-Zuhoor region (3 samples), Al-Muthana region (4 samples), and garden soils of Mosul University (3 samples).The soil samples were taken from places that are near the rhizosphere of garden plants (the non root-associated soil samples).

\section{Isolation of bacteria:}

One gram of each soil sample was putted in $9 \mathrm{ml}$ of sterilized distilled water then serial dilutions were done for each soil sample, and $0.1 \mathrm{ml}$ of the dilutions $10^{-4}$ and $10^{-5}$ of each sample was cultured on $9 \mathrm{~cm}$ Petri dish containing nutrient agar and incubated at $30{ }^{\circ} \mathrm{C}$ for 24 hour. The effect of the growing colonies colonies were tested against test fungi separately. The antifungal bacterial isolates were subcultured on nutrient agar slants for identification in which several morphological, physiological, and biochemical tests were done to identify these bacteria and their effects were tested against different pathogenic fungi.

\section{Antifungal bioassay test :}

In order to examine the antagonistic properties of bacterial isolates against phytopathogenic fungi, and according to Kobayashi et al.,2000 and Gupta et al.,2001 (9 and 10), an agar block (5 mm diameter) of 5day-old culture of fungal pathogen was placed in the centre of plate containing potato dextrose agar (PDA) (or Sabouraud dextrose agar in the case of human pathogenic fungi) (5). A loopful of 24-h-old culture of the each of the isolated bacterium was inoculated at $2 \mathrm{~cm}$ juxtaposed to the pathogen. Some plates were left without inoculation of the bacteria to serve as a control. The plates were incubated at $28 \pm 1{ }^{\circ} \mathrm{C}$ for 5 days and inhibition of fungal growth was measured.

\section{Results and Discussion}

\section{Isolation of antifungal bacteria:}

From thirteen different soil samples that were taken from different places in Mosul city, sixty six different bacterial isolates were obtained. Each one of these bacterial isolates was preliminary tested against the fungus Alternaria alternata .Seven different bacterial isolates showed an antifungal activities at first toward Alternaria alternata and later when tested against other fungi, and they were designated as AF1, AF2, AF3, AF4, AF5, AF6, and AF7.

\section{Identification of bacterial isolates:}

The antifungal bacterial isolates were subjected to several morphological, physiological, and biochemical tests to identify them (11 and 12), and the results were as follow: 
AF1, AF2,AF4,AF5, and AF6 isolates were identified as Pseudomonas spp.

AF3 and AF7 were identified as Paenibacillus spp. and Bacillus spp. respectively.

\section{Antifungal bioassay test:}

The seven bacterial isolates that preliminary showed antagonistic or antifungal activities were tested against different phytopathogenic fungi and against the human fungal pathogene Aspergillus niger. The isolates were ranked depending on the diameter of inhibition zone for fungi that caused by each isolate. The results are illustrated in (table 1) (see also figure 1 and figure 2):

Table (1): The bioassay test of the antifungal isolates

\begin{tabular}{|l|l|l|l|l|}
\hline \multirow{2}{*}{$\begin{array}{l}\text { Bacterial } \\
\text { Isolates }\end{array}$} & \multicolumn{4}{|c|}{ Inhibition Zone (mm) on: } \\
\cline { 2 - 5 } & $\begin{array}{l}\text { Fusarium- } \\
\text { graminearum }\end{array}$ & $\begin{array}{l}\text { Penicillium- } \\
\text { nalgiovense }\end{array}$ & $\begin{array}{l}\text { Alternaria- } \\
\text { alternata }\end{array}$ & $\begin{array}{l}\text { Aspergillus- } \\
\text { niger }\end{array}$ \\
\hline AF 1 & 2 & 0 & 5 & 0 \\
\hline AF 2 & 2 & 0 & 4 & 0 \\
\hline AF 3 & 5 & 5 & 7 & 4 \\
\hline AF 4 & 0 & 0 & 6 & 0 \\
\hline AF 5 & 2 & 0 & 6 & 0 \\
\hline AF 6 & 3 & 0 & 6 & 0 \\
\hline AF 7 & 6 & 4 & 7 & 3 \\
\hline
\end{tabular}

Form the above results, it is obvious that the antifungal bacterial isolates showed different antagonistic activities toward the selected pathogenic fungi, and this might be due to the different capabilities of each isolates to antagonize the different fungi, and also this might be due to the different antifungal metabolites that were produced and secreted by the different bacterial isolates (13). Many researches mentioned that the majority of existing biocontrol agents for management of soil-borne diseases were isolated from the rhizosphere(7). Also there is a possibility to explore antagonists from other habitats (such as non-rhizosphere soils, internal plant habitat, and seed surfaces) as potent biocotrol agents. This reflects our results in finding different antifungal bacterial species in the nonrhizosphere soil samples (14). Pseudomonas spp. are effective root colonizer and biocotrol agent by its production of antibiotics and other antifungal metabolites including hydrogen cyanide and siderophores (15, 16). Several Bacillus strains (such as B. cereus and B. subtilis) can protect plants from pathogens, and it is known that they produce several antibiotics and they are often found in soil and are associated with plants (17 and 18). Also it is well known, especially in recent years, that many species of the Gram positive Paenibacillus bacteria showed in vitro 
antagonistic activities against several fungal phytopathogens belonging to the ascomycetes, basidiomycetes, and oomycetes (19). From all above, it seems that our results were in agreement with many researchs in that different kinds of bacteria that are naturally inhabitant in the nonrhizosphere soils (such as Pseudomonas, Bacillus, and Paenibacillus) have an antagonistic activities against various phytopathogenic fungi and human pathogenic fungi and can be used as biocontrol agents. This activity may differ from one species to another depending on the nature of the antifungal organism(or the nature of the antifungal compound) or the circumstances and conditions that surround that organism. The results showed that Gram positive Paenibacillus and Bacillus spp. are more effective in antagonizing pathogenic fungi than Gram negative Pseudomonas spp. because they showed the higher inhibition zones toward the fungi, and that is in agreement with Danielsson et al.,2007 (20). Also in all above cases, the results showed that the best conditions for the production of the antifungal compound(s) from the isolated Pseudomonas, Paenibacillus, and Bacillus spp. was incubation at $28^{\circ} \mathrm{C}$ for 5 days and these are in agreement with Gupta et al., (2001) and Lee et al., (2008) (10 and 19).

Thus it was concluded that the non-rhizosphere soils may contain different potent antifungal bacterial growth. The Gram positive bacteria might be the most effective biocontrol agent, and their antagonistic activity was due to the production of antifungal metabolites.

Also it is recommended to make another study to compare the bioeffect of the different isolated antifungal bacteria from the non-rhizosphere, rhizosphere, rhizoplane and other different soil samples.

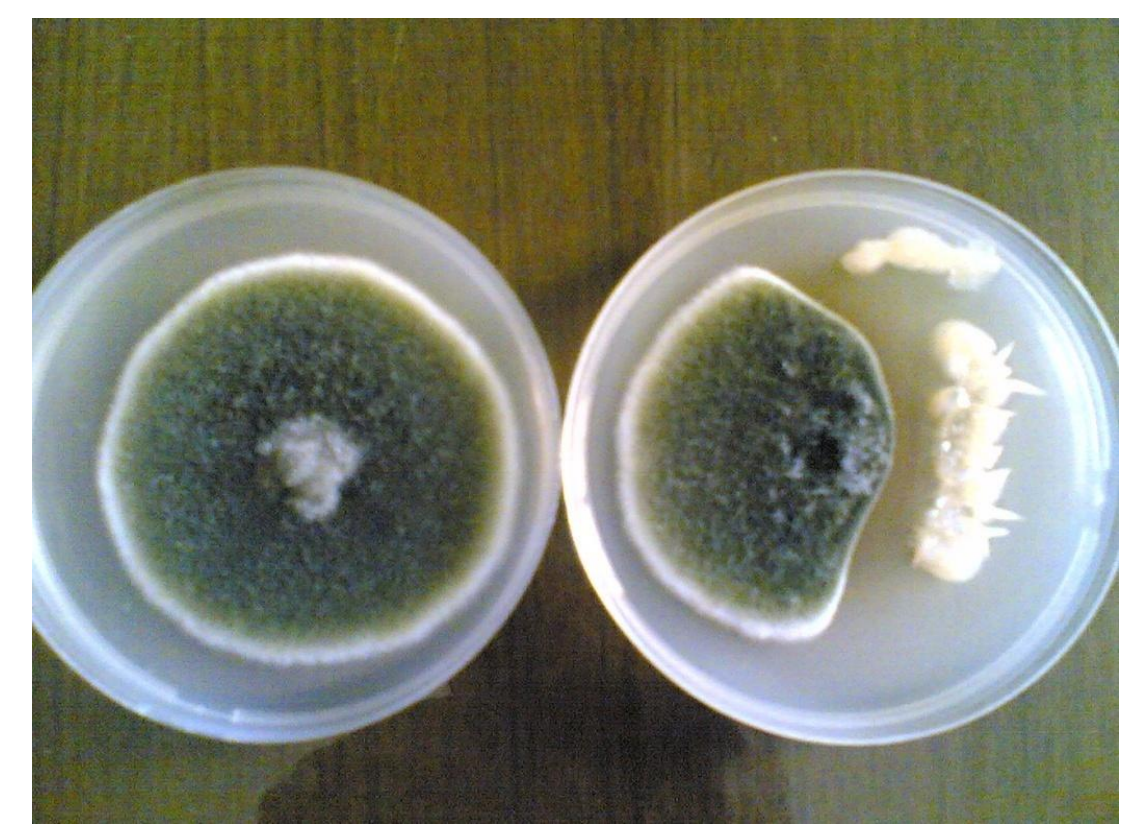

Figure(1): The bioeffect of the isolate AF3 on Alternaria alternata. 


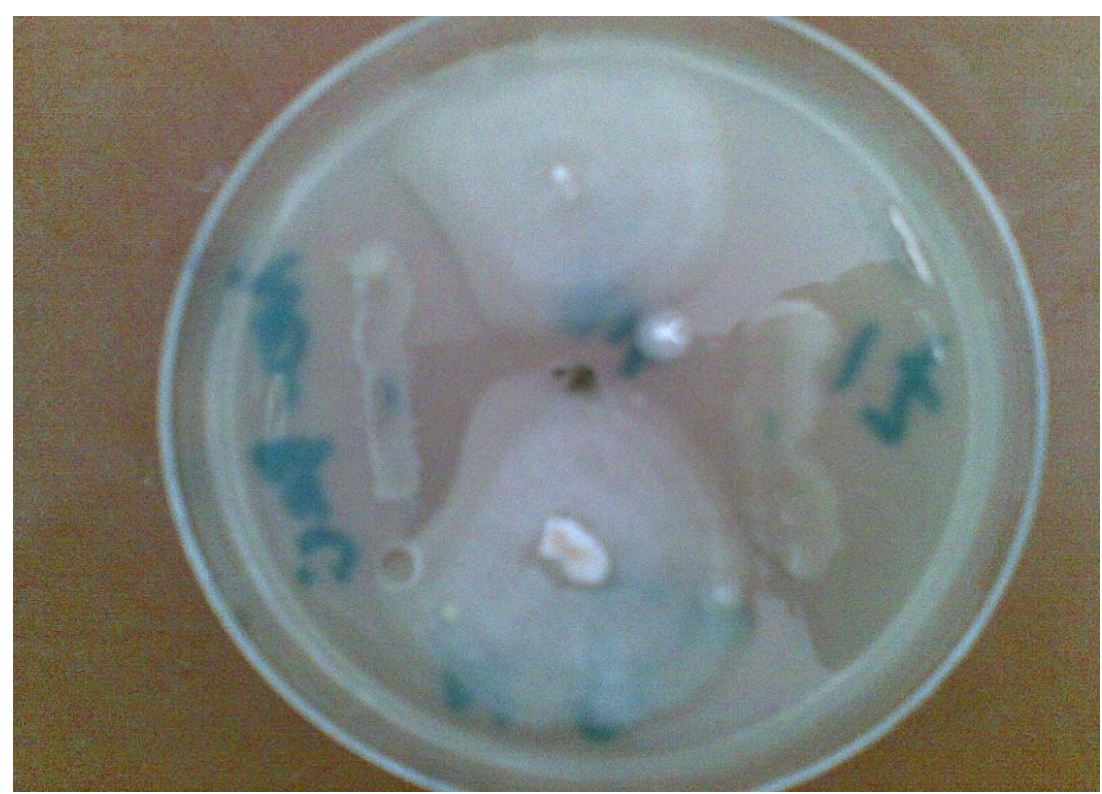

Figure(2): The bioeffect of the isolate AF7 (left) and of AF6 (right) on Fusarium graminearum.

\section{References}

1) Smith, D.R. and White, D.G. Diseases of corn. In Sprague, G.F. and Dudley, J.W. (ed.), Corn and corn improvement, 3 rd ed. American Society of Agronomy, Inc., Publishers, Madison, Wis. P. 687-768 (1988).

2) Shank, R.C. Role of aflatoxin in human disease. In Rodricks, J.V. (ed.), Mycotoxins and other fungal related food problems. American Chemical Society, Washington, D.C. P. 51-58 (1974).

3) Carlile, W.R. Fungicides. In W.R. Carlile (ed.). Control of crop diseases. Edward Arnold Publisher, London. P. 51-58 (1988).

4) Haggag, W.M. Colonization of exopolysaccharide-producing Paenibacillus polymyxa on peanut roots for enhancing resistance against crown rot disease. African J. Biotechnol. 6:1568-1577 (2007).

5) Jayaswal, R.K.; Fernandez, M.A.; and Schroeder, R.G. Isolation and characterization of Pseudomonas strain that restricts the growth of various phytopathogenic fungi. Appl. Environ. Microbiol. 56: 1053-1058 (1990).

6) Manjula, K.; Kishore, G.K.; Girish, A.G.; and Singh, S.D. Combined application of Pseudomonas fluorescens and Trichoderma viride has an improved biocontrol activity against stem rot in groundnut. Pl. Pathol. J. 20: 75-80 (2004).

7) Seldin, L.; Rosado, A.S.; da Cruz, D.W.; Nobrega, A.; van Elsas, J.D.; and Paiva, E. Comparison of Paenibacillus azotofixans strains isolated from rhizoplane, rhizosphere, and non-root-associated soil from maize planted in two different Brazilian soils. Appl. Environ. Microbio., 64: 3860-3868 (1998). 
8) Thomashow, L.S. Biological control of plant root pathogens. Curr. Opin. Biotechnol. 7: 343-347 (1996).

9) Kobayashi, K.; Laura, G.; Ana, V.; and Jorge, yC. Suppressive effects of antagonistic bacteria and metabolites on a pathogenic Rhizoctonia solani strain. Increased production in a specific medium. RIA. 29: 63-75 (2000).

10) Gupta, C.P.; Dubey, R.C.; Kang, S.C.; and Maheshwari, D.K. Antibiosis-mediated necrotrophic effect of Pseudomonas GRC2 against two fungal plant pathogens. Curr. Sci. 81: 91-94 (2001).

11) Holt, J.G.; Krieg, N.R.; Sneath, P.H.A.; Staley, J.T.; and Williams, S.T. Bergey's Manual of Determinative Bacteriology. Williams and Wilkins Press, London. P. 93, 94, 151- 157 (1994).

12) Forbes, B.A.; Sham, D.F.; and Weissfeld A.S. "Bailey and Scott's Diagnostic Microbiology". $7^{\text {th }}$ Ed. Mosby Elsevier, USA. P. $317-$ 324 (2002).

13) Guanlin, X., Pamplona, R., Cottyn, B. and Mew, T. W. Rice seedSource of naturally occurring biological control agents. In: Plant Growth Promoting Rhizobacteria: Present Status and Future Prospects, ed. by A. Ogoshi, K. Kobayashi, Y. Homma, F. Kodama, N. Kondo, and S. Akino. Proceedings of the Fourth International Workshop on Plant Growth Promoting Rhizobacteria, Sapporo, Japan. pp. 445 (1997).

14) Manjula, K., Singh, S. D. and Kishore, G. K. Role of endophytic bacteria in biological control of plant diseases. Annu. Rev. Plant Pathol. 1: 231-252 (2002).

15) O'Sullivan, D. J. and O'Gara, F. Traits of fluorescent Pseudomonas spp. involved in suppression of plant root pathogens. Microbiol. Rev. 56: 662-676 (1992).

16) Wang, S.L.; Yieh, T.C.; and Shih, I.L. Purification and characterization of a new antifungal compound produced by Pseudomonas aeruginosa K-187 in a shrimp and crab shell powder medium. Enzy. Microbia. Technol. 25: 439-446 (1999).

17) Yu G.Y., Sinclair J.B., Hartman G.L. and Bertagnolli B.L. Production of iturin A by Bacillus amyloliquefaciens suppressing Rhizoctonia solani. Soil Biol. Biochem. 34: 955-963 (2002).

18) Safdi, N., Cherif, M., Hajlaoui, M.R., Boudabbous, A., and Belanger, $\mathrm{R}$. Isolation and partial purification of antifungal metabolites produced by Bacillus cereus. Ann. Microbiol., 52: 323337 (2002).

19) Lee, Y.K., Senthilkumar,M., Kim, J.H., Swarnalakshmi, K., and Annapurna, K. Purification and partial characterization of antifungal metabolite from Paenibacillus lentimorbus WJ5. World J. Microbiol. Biotechnol. 24: 3057-3062 (2008).

20) Danielsson J., Reva O. and Meijer J. Protection of oilseed rape (Brassica napus) toward fungal pathogens by strains of plantassociated Bacillus amyloliquefaciens. Microb. Ecol. 54, 134-140 (2007). 